\title{
The Effect of Circuit Body Weight Training on the Muscle Strength of Basketball Players
}

\author{
$1^{\text {st }}$ Faza Annasai \\ Sport Science Faculty \\ Yogyakarta State University \\ Yogyakarta, Indonesia \\ fazaannasai.2020@student.uny.ac.
}

id

\author{
$2^{\text {nd }}$ Sigit Nugroho \\ Sport Science Faculty \\ Yogyakarta State University \\ Yogyakarta, Indonesia \\ sigit.nugroho@uny.ac.id
}

\author{
$3^{\text {rd }}$ Fuadi Raja Baja \\ Sport Science Faculty \\ Yogyakarta State University \\ Yogyakarta, Indonesia \\ fuadiraja.2019@student.uny.ac.id
}

\begin{abstract}
This research aims to determine the effect of circuit body weight training on the muscle strength of basketball players. This research used Pre-Experimental Design. Research and the design used the One Group Pretest-Posttest Design. Research population of basketball extracurricular players at SMA Negeri 1 Sanden, while the sampling technique used was purposive sampling with a total of 12 players. The instrument used was a leg and back dynamometer to measure the strength of the leg and back muscles and a hand dynamometer to measure hand muscles. Data analysis technique used hypothesis testing with $t$ test (paired sample $t$ test). The results showed that the percentage increase in leg muscle strength was $41.1 \%$, the percentage increase in back muscle strength was $58.3 \%$, and the percentage increase in hand muscles was $8.95 \%$. So, it can be concluded that there is a significant effect of circuit body weight training on the muscle strength of basketball players.
\end{abstract}

Keywords-Circuit Body Weight Training, Strength, Basketball

\section{INTRODUCTION}

According to [12], basketball has five players per team on the court. The purpose is to score points, make a goal and prevent another team to do the same thing [19]. Basketball basic techniques include footwork, shooting, passing, catching, dribbling, rebounding, moving without ball, moving with ball, and defending [19]. According to [14] stated that professional basketball players jump during the match with specific moves of basketball (for example, rebounding, dribbling, shooting, and blocking) done with high intensity and related to development of muscle strength and power, speed, and agility. [8] "Because success in sport often demands the perfect skill in high physical stress, it is clearer that physical condition play a very important role in improving athlete achievement". [18] The ones determining an athlete achievement are physical condition, techniques, tactics, and mental. It is not easy to get basketball sport achievement, with sustained training it will result the best achievement. In accordance with [1] training is a continuously systematic sport activity in a long time, improved progressively and individually leading to physiological and psychological function features of human beings to achieve determined goals.

There are some methods in physical component trainings able to improve physical strength, one of them is body weight training as weight. The existence of physical training method using own body weight or body weight training enables training done anywhere. Basketball player training needs to be improved in physical component through circuit training method. Circuit training is a training system able to improve simultaneously the whole body, namely endurance, strength, flexibility, power, muscle endurance, agility, speed and some other physical condition components [8].

According to [16] circuit training is aerobics training consisting of training posts namely about 8 to 16 posts by moving from post one to the next post to all posts. Circuit body weight training is the combination of aerobics and endurance trainings done in a short time dan can be done anywhere [3]. By having good physical condition, athletes can master and improve basketball basic techniques. According to [17] every sport branch has different muscel special strength element depending on predominant muscle needed and involved in its sport branch activity. Basketball basic techniques require special strenght because it depends on muscles involved in the activity. The player shooting the ball in order that it goes into basketball hoop requires enough arm muscle special strength so that the shooting can be done many times and score points, preparing position to rebound to 
jump in refusing to take the ball requires leg muscle special strength. The strenght improvement also results increase in muscle level and joint stiffness such as landing from offensive rebound and jumping to shoot the ball (jump shoot) [6].

\section{METHOD}

\section{A. Research Time and Location}

This research used Pre-Experimental design because this design has not been real experiment, there are still external variables participating to effect towards dependent variables forming [15]. Research design used One Group Pretest-Posttest Design using one subject group.

Research location was on SMAN 1 Sanden basketball court. Research time was in August September, 2019. The treatment was done in 18 meetings, with frequence 3 times in a week namely Tuesday, Thursday, and Saturday.

The population used in this study are SMA Negeri 1 extracurricular basketball players consisting of 15 male players. This consideration is based on: (1) SMA Negeri 1 Sanden basketball extracurricular active players, (2) aged 15-17 years old, (3) male gender, (4) willingness and sincerity to be samples. Those who meet the criteria are 12 SMA Negeri 1 Sanden basketball extracurricular male players. Data population were collected during first and last test. Besides that, the instruments used to measure strenght were hand dynamometer and leg and back dynamometer.

\section{B. Data Analysis}

Normality tester used SPSS 25 for Windows Evaluation Version program with KolmogorovSmirnov formula. The criteria used to know whether a scatter is normal or not are if $\mathrm{P}>0.05(5 \%)$, the scatter is claimed normal, and if $\mathrm{P}<0.05(5 \%)$, the scatter is claimed not normal. Hypothesis test used t-test with SPSS program by comparing data mean obtained from pretest and postest with significance $5 \%$ or 0.05 using SPSS 25.

\section{Circuit Training Program}

Training frequence is 3 times per week, set is $2-3$, training intensity in every post is 30 seconds to do every move with rest between posts 10-20 seconds and rest between sets 60-180 seconds. Circuit body weight training in this study consists of 10 posts namely, Shuttle Run 10m, Hindu Push Up, Reverse Crunch, High Knee, Squat Trust, Plank, Kneeling Hip Extension, Lunge, Tuck Jump, Jumping Jack.

\section{RESULT AND DISSCUSION}

\section{A. Result}

This study aims to know the effect of circuit body weight training towards basketball player strength involving hand, back, and leg muscle strength.

Table 1. Descriptive Statistics

\begin{tabular}{|l|c|c|c|c|}
\hline & Minimum & Maximum & Mean & $\begin{array}{l}\text { Std. } \\
\text { Deviatio } \\
\mathrm{n}\end{array}$ \\
\hline $\begin{array}{l}\text { Pretest } \\
\text { Hand } \\
\text { Dynamomet } \\
\text { er }\end{array}$ & 27,10 & 37,50 & 33,291 & 3,152 \\
\hline $\begin{array}{l}\text { Posttest } \\
\text { Hand } \\
\text { Dynamomet } \\
\text { er }\end{array}$ & 30,60 & 39,90 & 36,266 & 3,184 \\
\hline $\begin{array}{l}\text { Pretest Back } \\
\text { Dynamomet } \\
\text { er }\end{array}$ & 60 & 85 & 73,750 & 7,794 \\
\hline $\begin{array}{l}\text { Posttest } \\
\text { Back } \\
\text { Dynamomet } \\
\text { er }\end{array}$ & 97 & 135 & 116,750 & 11,038 \\
\hline $\begin{array}{l}\text { Pretest Leg } \\
\text { Dynamomet } \\
\text { er }\end{array}$ & 75 & 230 & 138,666 & 51,693 \\
\hline $\begin{array}{l}\text { Posttest Leg } \\
\text { Dynamomet } \\
\text { er }\end{array}$ & 145 & 276 & 195,666 & 40,661 \\
\hline N $=12$ & & & & \\
\hline
\end{tabular}

Based on study result in the table 1 , the percentage increase in hand muscle strengh is $8.95 \%$, the percentage increase in back muscle strength is $58.3 \%$, the percentage increase in leg muscle strength is $41.1 \%$.

Table 2. Normality Test

\begin{tabular}{|l|c|c|c|}
\hline \multirow{2}{*}{ Variabel } & & $\begin{array}{c}\text { Kolmogoro } \\
\text { v-Smirnov } \\
\mathbf{Z}\end{array}$ & Asymp.Sig \\
\hline Hand & Pretest & 0,140 & 0,200 \\
\cline { 2 - 4 } Dynamometer & Posttest & 0,222 & 0,104 \\
\hline Back & Pretest & 0,205 & 0,173 \\
\cline { 2 - 4 } Dynamometer & Posttest & 0,133 & 0,200 \\
\hline Leg & Pretest & 0,163 & 0,200 \\
\cline { 2 - 4 } Dynamometer & Posttest & 0,187 & 0,200 \\
\hline
\end{tabular}

Based on results in the table 2, it is known wholly that pretest data of hand muscle strength is with $\mathrm{p}$ $(0.200)>0.05$, posttest of hand muscle strength is with $\mathrm{p}(1.04)>0.05$, pretest data of back muscle strength is with $\mathrm{p}(0.173)>0.05$, posttest of back muscle strength is with $\mathrm{p}(0.200)>0.05$, pretest data of leg muscle strength is with $p(0.200)>0.05$, and posttest of leg muscle strength is with $\mathrm{p}(0.200)>$ 0.05. it can be concluded that the distribution of the data is normal. 
Table 3. Paired Sample Test

\begin{tabular}{|c|c|c|c|c|c|c|c|c|}
\hline \multicolumn{9}{|c|}{ Paired Samples Test } \\
\hline & \multicolumn{5}{|c|}{ Paired Differences } & \multirow[b]{3}{*}{$\mathrm{t}$} & \multirow[b]{3}{*}{ df } & \multirow{3}{*}{$\begin{array}{l}\text { Sig. (2 } \\
\text { tailed) }\end{array}$} \\
\hline & \multirow[b]{2}{*}{ Mean } & \multirow{2}{*}{$\begin{array}{c}\text { Std. } \\
\text { Deviati } \\
\text { on }\end{array}$} & \multirow{2}{*}{$\begin{array}{l}\text { Std. } \\
\text { Error } \\
\text { Mean }\end{array}$} & \multicolumn{2}{|c|}{$\begin{array}{l}95 \% \text { Confidence } \\
\text { Interval of the } \\
\text { Difference }\end{array}$} & & & \\
\hline & & & & Lower & Upper & & & \\
\hline \begin{tabular}{|l|l|} 
Pair & Pre_Hand_D \\
1 & ynamometer - \\
& Post_Hand_D \\
& ynamometer
\end{tabular} & $\begin{array}{c}- \\
2,975 \\
00\end{array}$ & 2,18179 & ,62983 & $\begin{array}{c}- \\
4,36125\end{array}$ & \begin{tabular}{|c|c} 
& - \\
\end{tabular} & $5 \mid$\begin{tabular}{c|} 
\\
\end{tabular} & 11 & ,001 \\
\hline \begin{tabular}{|l|l|} 
Pair & Pre_Back_Dy \\
2 & namometer - \\
& Post_Back_D \\
& ynamometer \\
\end{tabular} & $\begin{array}{c}- \\
43,00 \\
000\end{array}$ & $\begin{array}{c}11,4256 \\
5\end{array}$ & 3,29830 & $\begin{array}{c}- \\
50,2595 \\
1\end{array}$ & $\begin{array}{c}- \\
35,7404 \\
9\end{array}$ & $4\left|\begin{array}{c}- \\
13,03 \\
7\end{array}\right|$ & 11 & ,000 \\
\hline \begin{tabular}{|l|l|} 
Pair & Pre_Leg_Dyn \\
3 & amometer - \\
& $\begin{array}{l}\text { Post_Leg_Dy } \\
\text { namometer }\end{array}$ \\
\end{tabular} & $\begin{array}{c}- \\
57,00 \\
000\end{array}$ & $\begin{array}{c}34,3273 \\
0\end{array}$ & 39,90944 & $\begin{array}{c}- \\
78,8105 \\
3\end{array}$ & $\begin{array}{c}- \\
55,1894 \\
7\end{array}$ & 45,752 & 11 & ,000 \\
\hline
\end{tabular}

Table 3 showed t-test results using paired t-test analysis. Based on calculation results in analysis, it is known that hand dynamometer t-test is 4.723 with significance $0.0001<0.05$, back dynamometer is 13.037 with significance $0.000<0.05$ and leg dynamometer is 5.752 with significance $0.000<0.05$, it means that there is circuit body weight training effect towards hand, back, and leg strength of basketball game.

\section{B. Disscusion}

The study results showed that there is an effect of circuit body weight training towards basketball game hand, back, and leg strength. Basketball is a sport utilizing physical condition especially strength to master basketball basic techniques or tactics. To own basketball skills, you have to train physical component especially strength. So that the training includes theoretical and practical material, methods, and rules in accordance with goals and objectives achieved [17]. Training function is done to load muscles group targeted progressively by choosing various trainings so that it can help to change muscles activation and adaptation [5]. Targeting specific muscles can use training regularly with increase in training load gradually and varied. Strength training with load training using body weight does not only train strength. It also has another aim namely increase in size of muscle fibers [10]. According to [13] muscle strength is determined based on the size of muscle fibers so that in order to increase muscle strength, it is done by increasing muscle mass and size.

Using circuit training system has an effect towards strength. Circuit training is very effective and can be applied to increase in functional strength and fitness [4]. Meanwhile, in accordance with [7] circuit training approach enables individual who is overweight or having obesity to increase fitness and strength so that it functions good first move in training program. Circuit training using load (weight) with rest 3 minutes can provide more effective results to increase aerobic endurance in beginner basketball athlete aged 16 years old [9]. Therefore, circuit training is a training system that can affect various physical and fitness components.

Training in accordance with training principles guide plays a very important role towards athlete physiological and psychological aspects circuit training have principles that overload as load training has to be increased gradually in accordance with frequency, intensity, and duration [11]. Training in this study has principles that overload in every 6 session is increased. According to [17] training load is increased progressively after 3 weeks or 6-8 training sessions. The way to increase progressively are (load amount, repetition set, series/circuit). Therefore, circuit body weight training has to be adjusted to physical component demands especially strength in a match. Circuit body weight training is done during 6 weeks with frequency 3 times/ week. According to [13] training with muscle maximum contraction with frequency 3 times per week gradually during 6-8 weeks can increase muscle strength by $30 \%$. Study conducted by [2] showed that training load is progressively higher during 6 weeks using plyometric with one foot move than with two feet. Therefore, this study was done with 3 times per week training and training load increased during 6 weeks that is realized physical fitness especially strength.

\section{CONCLUSION}

Based on result and discussion above, it is known that the percentage increase in hand muscle strengh is $8.95 \%$, the percentage increase in back muscle strength is $58.3 \%$, the percentage increase in leg muscle strength is $41.1 \%$. Based on that, it can be concluded that circuit body weight training can effect towards basketball player hand, back, and leg muscle strength.

\section{REFERENCES}

[1] Bagus W, I. (2017). Teori dan Aplikasi Latihan Kondisi Fisik. Depok: Rajawali Pers.

[2] Bogdanis, D. C., Tsoukos, A, Kaloheri, O. et al. (2019). Comparison Between Unilateral And Bilateral Plyometric Training On Single- And Double-Leg Jumping Performance And Strength. Journal of Strength and Conditioning Research, 33(3), 633-640

[3] Brett Klika \& Chris Jordan. (2013). High Intensity Circuit Training Using Bodyweight. ACSM's Health \& Fitness Journal. Volume 17. No. 3. Hal. 8-13.

[4] Cardozo, D. C., DE Salles, B. F., Mannarino, P., Vasconcelos, A. P. S., Miranda, H., Willardson, J. M., \& Simão, R. (2019). The Effect of Exercise Order in Circuit Training on Muscular Strength and Functional Fitness in Older Women. International Journal of Exercise Science, 12(4), 657-665. 
[5] Cavarretta, D. J., Hall, E. E., \& Bixby, W. R. (2018). The acute effects of resistance exercise on affect, anxiety, and mood - practical implications for designing resistance training programs.International Review of Sport and Exercise Psychology,1-30. doi:10.1080/1750984x.2018.1474941

[6] Cole, B., \& Panariello, R. (2015). Basketball Anatomy. In Human Kinetics.

[7] Davis, J. N., Gyllenhammer, L. E., Vanni, A. A., Meija, M., Tung, A., Schroeder, E. T., Spruijt-Metz, D., \& Goran, M. I. (2011). Startup circuit training program reduces metabolic risk in latino adolescents. Medicine and Science in Sports and Exercise, 43(11), 2195-2203. https://doi.org/10.1249/MSS.0b013e31821f5d4e

[8] Harsono. (2018). Latihan Kondisi Fisik Untuk Atlet Sehat Aktif. Bandung: PT Remaja Rosdakarya.

[9] Herdiyana Bastian, R., \& Tomoliyus, M. (2019). Bodyweight Circuit Training for Basketball Beginner Athletes' Aerobic Endurance. 278(YISHPESS), 554-557. https://doi.org/10.2991/yishpess-cois-18.2018.140

[10] Mansur, L. K., Irianto, J. P., \& Mansur, M. (2018). Pengaruh latihan squat menggunakan free weight dan gym machine terhadap kekuatan, power, dan hypertrophy otot. Jurnal Keolahragaan, $6(2)$

$150-161$.
[11] Mylsidayu, A \& Kurniawan, F. (2015). Ilmu Kepelatihan Dasar. Bandung: Alfabeta

[12] Oliver, J. (2007). Dasar-dasar Bola Basket. Bandung: Pakar Raya.

[13] Penggalih, M.H.S.T (2019). Respons, Adaptasi Biokimia, Dan Fisiologi Atlet. Yogyakarta: Gadjah Mada University Press.

[14] Puente, C., Abian-Vicen, J., Areces, F., \& et al. (2017). Physical And Physiological Demands Of Experienced Male Basketball Players During A Competitive Game. Journal of Strength and Conditioning Research, 31(4), 956-962.

[15] Sugiyono. (2015). Metode Penelitian Kuantitatif, Kualitatif dan R\&D. Bandung: Penerbit Alfabeta.

[16] Suharjana. (2013). Kebugaran Jasmani. Yogyakarta: Jogja Global Media.

[17] Sukadiyanto \& Muluk. (2011). Pengantar Teori dan Metodologi Melatih Fisik. Bandung: CV. Lubuk Agung.

[18] Syafruddin. (2012). Pengantar ilmu melatih. Padang: UNP Press.

[19] Wissel, H. (2000). Bolabasket: Langkah Untuk Sukses. Jakarta: PT Raja Grafindo Persada. 